\title{
Entrepreneurial Intention among Postgraduate Students in Nigerian Universities: Conceptual Review
}

\author{
Adamu Abdullahi Idris ${ }^{1}$
}

\begin{abstract}
${ }^{1}$ School of Business Management, Universiti Utara Malaysia, Malaysia
Correspondence: School of Business Management, Universiti Utara Malaysia, Malaysia, E-mail: adamabdullahidris584@gmail.com
\end{abstract}

Received: September 01, $2017 \quad$ Accepted: September 11, $2017 \quad$ Online Published: September 23, 2017

\begin{abstract}
Governments in most developing countries are doing their best to ensure that graduates who are not employed should engage in entrepreneurship activities which can go a long way in reducing the problem of unemployment among the youths. Nigeria is among one of those developing nations with such problem. The government has introduced some many programs and policies which are aimed at reducing poverty and will encourage self-employment among the youths. Yet, students are still lacking the intention of becoming entrepreneur. From this study, there will be need to cover the gap found in the literature and then developed a conceptual framework (from which propositions where developed. The study used factors such as entrepreneurship education, environmental factors and societal entrepreneurship attitude to explore the student's entrepreneurial intention. These factors where adopted bases on past theoretical and empirical studies which will cover the gap and contribute to the body of knowledge in the field of literature. Finally, this study calls upon researchers and Ministry of Education to examine this propositions on how to design a more comprehensive and benefice entrepreneurship courses and curriculum to these Nigerian universities. This will aim at preparing these students to be self-employed (entrepreneurs) which will reduce and assist the government in overcoming the problem of youth poverty and unemployment in Nigeria.
\end{abstract}

Keywords: Entrepreneurial intention, entrepreneurial education, environmental factor, societal entrepreneurship attitude.

\section{Introduction}

The challenges currently faced by most developing countries in the world are how to involve their teeming youths in advantageously employed. The growing rate of unemployment among the graduate youths as a result of delays in getting jobs that harmonized their professions and expectations has therefore become the core goal of intense to both academicians as well as manager's evaluation (Aliman \& Jalal, 2013). Moreover, an irregularity that exists between theratio in demand for labour and the total number of graduates that are seeking for jobs also grounds to a strong level in the rate of unemployed youth (Ismail, 2011). One strategy which can be used to overcome this problem is to increase the level of entrepreneurship spirit, particularly for unemployed graduates (Othman \& Ishak, 2009). Entrepreneurship is one of the main options use by students when they graduate from school (Ekpoh \& Edet, 2011). Student engaged in it because entrepreneurship offers a lot of 
benefits, such as starting their own private business and the possibility for getting substantial rewards (financial) than when they work for others. This has shown how entrepreneurship development plays an important function or role in a nation's economic development and growth. Experts have proven that the economic transformation in the United States of America that lead to the achievement as one of the best economic nation was as a result of entrepreneurial activities, so entrepreneurship is the bedrock of both developed and developing nations (Akinola, 2013).Similarly, Lucky and Minai (2011) added that entrepreneurship is a dynamism for both economic development and economy. It was noted that entrepreneurship development can create wealth, provide jobs and contribute meaningfully to a country's gross domestic product (GDP). Also Karimi, Chizari, Biemans, \& Mulder (2010) added to the significance of entrepreneurship on the role it plays in solving problems faced by most developing economies, how it provide employment and the attraction it have drawn from the developing countries and how those countries have adapted with the various entrepreneurship programs. Earlier, before the advent of colonial rule, unemployment was a rare phenomenon in Nigeria because the people were highly entrepreneurial and productively engaged, mostly in agricultural activities. However, the emergence of colonial administration in Nigeria introduced formal education, which enabled people to have the opportunity of being employed in the civil service after graduation. As such, the system of administration destroyed self-reliance, self-employment and entrepreneurial skills of Nigerians as they became permanently dependent on the colonial masters (Raimi and Adeleke, 2010). This has led to massive unemployment and craze in the contemporary times for ready-made jobs. This craze reached its height in the 1990's, leading to a phenomenal increase in the number of graduates seeking paid employment in the civil service and in the private sector of the Nigerian economy.

Nigeria is one of the developing nations which face the problem of youths graduate every year from various universities and colleges without getting a job that match them (Akanbi, 2013). For example, on March, 15th, 2014 over twenty thousand $(20,000)$ graduate seeking for the job applied for the job in the Nigerian Immigration Service (NIS). In the process of the recruitment test over seven applicants died in the screening process as a result of (stampeding) high number of unemployed graduates in the country seeking for a job (Premium Times, 2014). Also the other issue that contributed to the high unemployment rate in Nigeria was as a result of poor implementations of the socioeconomic policies and the instability in the political setting of succeeding government in Nigeria (Ogundipe \& Kosile, 2012). It was also noted that one of the main challenges unemployed youths faces is that they were being used as political thugs during the election time (Awogbenle \& Iwuamadi, 2010). These youths become gangsters and engage in secrete political and anti-social activities in the society. Therefore, this pressed the government to induct various policies which aimed at reducing poverty through the encouragement of stimulates innovation spirit, skill attainment and youth self-independent programs (Agbim et al, 2013).

\subsection{Problem Statement}

There are rising concerns over the enticement state of young entrepreneur in Nigeria. The government and people of Nigerians are having substantial worries about the poor state which Nigeria entrepreneurship is in. One of the major challenges faced by the Nigeria education is the inability of the colleges and universities to prepare graduates and students to be entrepreneurs or to be self-reliant (Agbim, Oriarewo \& Owocho, 2012). As a result of this, most students or graduates preferred to be employed by private or government sectors than to become self-employed or self-reliant. National Bureau of Statistics (2014) has shown that the rates of unemployed people in Nigeria are students from universities and these students cannot be employed all by both sectors (private and government). So therefore, the Nigeria Federal Ministry of Education has to review the 
education curriculum of subject or courses which is being offered in the colleges and universities to see that student are been encourage and trained to be self-employed and self- reliant, if not it will create room for those student that are not able to gain employment to involve in criminal, religious and ethnic crisis which youths are used for (Akanbi, 2013).

Entrepreneurial activities have enhanced both social and economic development. The majority of the developing countries (Nigeria) depend solidly on the foreign nation such as the United States and others for their export and investments to boost its economy. (Griffith-Jones \& Ocampo, 2009). Nigeria is set to be a vulnerable country if the government fails to encourage and provides incentives to youths to start-up a business. Past studies have shown few individual that have certain characteristics can venture and strived into setting up business enterprises (Akanbi, 2013; Agbim, Oriarewo \& Owocho, 2012). But the reasons to why people established or what drive them into creating these new enterprises remain unanswered. The enthusiasm of the world today in which modifications keep on evolving is necessitated a rebirth of the events of entrepreneurship happening. Experience that established big firms which are no longer creating a net increase in the employment has drawn into considerations of encouraging new formations of business as it set to create new jobs. Thus, Opportunity becomes very important for people strive and set up their business that will make them self-employ (Owoseni, 2014). This will result in academic interest of entrepreneurship as an act of creating and making new independent businesses. This follows a dire need to know the individual that stand a great chance of involving into entrepreneurship, but this has to go beyond wanting and inquiring to understand what makes individual start up new business ventures. Therefore, the study about entrepreneurial intentions is very necessary because it helps and offers a better means of explaining entrepreneurship.

Also, it is very critical to understand and focus on the factors which affect student's intentions to startup a business venture in the future. Henderson and Robertson (2000) added that working environment also create and motive individual, especially the graduates to have the intention of starting up their own business. Furthermore, to identify motivation and the perceived or actual barriers in the formatting of new businesses is very important. With the increasing number of students graduating from Nigeria colleges and universities without being employed have become a nightmare for the government to handle. Despites highest academic qualification of these students, but still unemployed. According to the new president of Nigeria Muhammad Buhari, when he was been interviewed by BBC (Hausa) on youth development and empowerment, where he estimated over two million graduates from Nigeria University and colleges are still unemployed eight months after their graduations. However, the numbers of start-up business are increasing, but it's not all graduates that have the opportunity to set up something. Thus, some effort has been made by both government and non-government bodies to increase and implementing programs and incentives that will benefit these students in setting their own business.

2. Literature review

\subsection{Entrepreneurship}

Entrepreneurship concepts, development and activities are highly essential (Singh, Fahmi \& Riaz, 2011), because it is one of those driving factors that develop an economy by a way of wealth creation and job creation (Temtime, Chinyoka \& Shunda, 2004). An entrepreneur has consequent a key number of concept such as entrepreneurial and entrepreneurship (Wickham, 2001). He stated that the concepts of entrepreneurship cover what the entrepreneur should do and while entrepreneurial defines how the entrepreneur should undertakes what he or she needs to do. The attitude puts towards entrepreneurship have a stronger predictor of entrepreneurial intention rather compared to subjective norms and perceived control behaviour (Malebana, 2014). Past 
researches have pointed out that the approach towards entrepreneurship is being affected either intrinsic and extrinsic motivation or one of this motivational factors, example, earning and ownership (Douglas \& Fitzsimmons, 2013), self-actualization, gain a comfortable earning and freedom (Fretschner \& Weber, 2013) role, recognition and self-realization (Saeed, 2013). An individual can be affected when observing on the existing entrepreneurs. It can be either a negatively or positively affection, this can equally affect attitudes in the direction of entrepreneurship and entrepreneurial intention (Muofhe \& du Toit, 2011).

\subsection{Entrepreneurial Intention among Postgraduate Student}

Scholars have researched and used so many approaches to find the factors which could lead to an individual intention to start up his or her business such as personality traits (Akanbi, 2013; Owoseni, 2014), Values, attitudes and beliefs (Gasse \& Tremblay, 2011), demographic variables and perception of barriers such as gender, age (Deh, assume \& Agyemang, 2013) and student level of studies (Bhandari, 2013) which were analysed for their concepts, low explanatory capability and problematic methodologies (Karali, 2013). This was supported by Bates, Maechler, Barker and Walker (2013) as they stated that individual factors, situational factors, demographic variables and economic factors have a low average strength when predicting an entrepreneurial activity. They also pointed out from the entrepreneurship perspective, where they viewed intention as a very important element when establishing a business. Bates et al. (2013) added that an individual who has an opportunities to set up a business and have the capability to get involve into entrepreneurship but also lack the entrepreneurial intention, might not like to involve into business or any risk of such nature. With this it is paramount to have entrepreneurial intentions which will encourage starting up a new business or entrepreneurship activities.

Entrepreneurial intention can be defined as a person willingness to involve in entrepreneurial activities, to be self-reliant and to perform entrepreneurial behavior (Dohse \& Walter, 2010). It takes ambition, guts and inner courage for an individual to set up a new business. Ismail, Khalid, Othman, Jusoff, Rahman, kassim and Zain (2009) stated that an individual may have potentiality to be an entrepreneur or possess certain qualities and furthers but lack the intention and also the conversion of entrepreneurial activities. Therefore, to investigate the individual's intention towards self-employed will offer a meaningful inspiration for researchers to apprehend and forecast entrepreneurial stages and entrepreneurship activities which can be successful in a way of setting out the important of entrepreneurial intention (Ismail, et al., 2009). Entrepreneurial intention was also defined to be the self-acknowledged belief of an individual mind which can give him or her opportunity of setting up a business with sincerity and dedicate a plan for it in a point in time (Thompson, 2009). He further added that entrepreneurial intention concept will be determined by the strength of the individual intention of setting up a new business venture.

Also, Lucky and Minai (2011) argued that the opportunity for an individual to become an entrepreneur can be influenced base on his attitude. This will result on the type of attitude an individual put towards his intention in business. This intention could be positive or negative, assuming an individual put a positive intention; it will help in guiding and motivating the individual intention while if he or she decide to have negative intention, it will demoralized and discourage the individual. However, there is continues debates on which theories that is comprehensive focuses on the study and attributes of intention. Rodrigues, Dinis, do Paco, Ferreira and Raposo (2012), stated psychological approach focuses on traits and some personality attributes as determinant factors in intention to be self-employed, these will include; goal orientation, risk taking, internal locus, high need of achievement etc. 


\subsection{Entrepreneurship Education}

Entrepreneurship education can be said to be the key that leads to national development. This is because it leads to unlocks of the economic potentials in the people; equips individuals, empowers the society and value of the national economy, which provides the basis which is needed for the transformation and enables economic development. It is an important tool for the sustainability and job creation (Aluwong, 2010). Entrepreneurship education was defined as a part in the educational system which involves skills acquisition, management abilities and ideas that necessitate the intention of people (Maina, 2014). This perception draws consideration to the importance of developing the capabilities and social supports that will enable the individuals living in high poverty to pursue entrepreneurship as the valued choice rather than inevitability in the absence of substitute earning opportunities (Gries and Naudé, 2011).

In addition, it is also refers to the development of skills and knowledge either "for the purpose" or "about" entrepreneurship generally, like the familiar education system at primary, secondary and tertiary education institutions (Global Entrepreneurship Monitor, 2010). It was also defined as the training an individual's received in regards to entrepreneurship; it can be knowledge or skills which an individual possesses over some period of time and in a given field (Ekpe \& Mart 2012). It was further defined as the programs which student undergo in order to provide them with the basic information and skills concerning their future career as an entrepreneur (Ekpoh \& Edet, 2011 and Ooi, Selvarajah and Meyer, 2011). Ediagbonya, (2013) view Entrepreneurship education as a kind of training which assist the participants in building their entrepreneurial qualities by backing them up with some service which can lead them to successfully starting up a new ventures.

\subsection{Entrepreneurship Education and Entrepreneurial Intention}

Studies have shown that there are significant relationships between Entrepreneurship education and entrepreneurial intention. According to Dohse and Walter (2010) argued that students with entrepreneurial knowledge (education) have a high positive relationship with the entrepreneurial intention to start a business than those students who don't have the knowledge. They added by providing three reasons which entrepreneurial knowledge became a background for entrepreneurial intention. Firstly, students that attend entrepreneurial classes, generate ideas and learn techniques on how to set up is own venture, (e.g. Technique Innovative) and to be able to analyzed whether those ideas are worthwhile (e.g. Analyses of business). Second reason is that, all the number of courses ponders the level of departments' reflecting the self-reliance as a certified career choice. Last, entrepreneurship education suggests ways to improve a student's business ideas and how to make opportunities from it than others. Besides, there is a positive significant difference in intention among those student that took the course and those who did not undergo the entrepreneurship education program (Zain, Akram \& Ghani, 2010; Palmer \& Gonzalez, 2009). From the study of Zwan, Zurrhout and Hessels (2013) stated that there is an existing positive relation between entrepreneurship learning and individual intention.

\subsection{Environmental Factors}

Environmental factors are those components outside an organization which will have impact on the organization either negatively or positively (Frederick, Kuratko \& Hodgetts, 2006). Baldacchino and Dana (2006) called environmental factor as "external components" or "external factors" which play an important role in the creation of a business organization. They added that environmental factor has positive influence on people and organizations since those factors have provided a flourishing environment. It was also defined as the influence and support acquired outside an organization which can be referred to as the environment influence or 
environment support (Fini, Grimaldi, and Sobrero, 2009). Fini, et al. (2009) in their study will operationalize environmental factors as environmental influence and environmental support which will be capable to influence the entrepreneurial intention among postgraduate students in universities. According to Lucky, Hamzah and Minai (2013) confirmed that the studies of entrepreneurship without referencing to environment will be considered as incomplete and insufficient. The environmental factors can be divided into two Environmental supports andEnvironmental influences.

\subsection{Environmental Supports}

Environmental supports in business plays an important role in influencing an individual entrepreneurial activity. Which scholars have associated Environmental supports with the role government play in supporting entrepreneurship. These roles that government plays can comes in terms of programs and policies such as externalities, infrastructures and funding (Fini et al, 2009). They forward added that universities environment is also recognized as an important mechanism which influences entrepreneurial intention. Esuh and Najafi (2014) stated that Environmental supports can be ways in which government support entrepreneurs in terms of motivating and encouraging people to become entrepreneurs, these supports can be in a form of government patronizing these entrepreneurs products or services, tax holiday and grant. Many scholars have identified that resources can make an environment more supportive to entrepreneurial activities as tangible and intangible (Beck, Demirgüç - Kunt, \& Maksimovic, 2005). These resources identified are training, plan competition and business idea as (intangible) and financial support and soft loans as (tangible), the most important part is the physical structure support within the environment.

\subsection{Environmental Influence}

Environmental influences can be said to be the characteristics and nature of the environment in terms of competitive changes and nature that are normally the circumstances in a business venture (Fini, Grimaldi, Marzocchi, \& Sobrero, 2009). They added an assumption that, the more an environmental dynamism the more the need for innovation that will meet the demand in the changing environment. The further argued that organization which operate in different markets tend to have greater experience in dealing with competitors and customers as they have more ideas as a result in their diversity nature of markets operation. The greater diversity in an organization's marketing operation the more innovation in terms of entrepreneurial activities. Miller and Friesen (1983) added that perception of different structures and understanding, programs and policies, administrative and personnel differences displayed are combinations of results that will educate, guide and motivate individual in in considering and emerging new ideas.

\subsection{Environmental Factor and Entrepreneurial Intention}

Studies have shown that there are significant relationships between environmental factors and entrepreneurial intention (Esuh and Najafi, 2014; Uddin \& Bose, 2012). The universities should play a key role in determining students' entrepreneurial intention by providing to them facilitating environment that will aid their intention toward becoming an entrepreneurs (Abdullah, Hamali, Deen, Saban, \& Abdulrahman, 2009 and Lucky \& Minai, 2011). They further added that, the environmental factors contribute highly for a student to have an effective entrepreneurial intention and may lack the entrepreneurial intention when he or she doesn't have an enabling environment support. This is a major challenge face by students in the institution towards building their entrepreneurial intention.

In addition, Abdullahi, Hamali, Deen, Saban and Abdulrahman (2009) stated that the environmental factors has a positive role it plays in influencing entrepreneurial activities and the impact of the development of firms in the 
society. Similarly, Uddin and Bose (2012) in their study found a very strong correlation between environmental factors and entrepreneurial intention. They also added that the existing relationship between environmental factors and entrepreneurial intention is worth studying. Environmental factor plays an important role when determining the possibility of an individual to become an entrepreneur (Lucky \& Minai, 2011). They continued their argument that an enabling environment can assist people to think of having intention for entrepreneur.

\subsection{Societal Entrepreneurship Attitudes and Entrepreneurial Intention}

Researchers have view entrepreneurship attitude from two main approaches. Ajzen and Fishbein (1977) view the first approach of entrepreneurship attitude as an individual thoughts, conations and feeling toward entrepreneurship. Therefore, entrepreneurial intention will be a function of attitude toward benefit, favorability and value of entrepreneurship while Robinson, Stimpson, Huefner, and Hunt (1991) view the second approach of entrepreneurship attitude as a multi- dimension concept which has four personality factors such as need for achievement, perceptions of influence and control on business creation, innovation and self-esteem. Entrepreneurship attitude is been analyzed as social welfare attitudes, it is refers to as attitude which will target social welfare such as people's responsibility for their well-being and income, society's responsibility, customer relationship and social services or other social welfare objective (Linan \& Chen, 2009). They added that the effect of societal attitude and perceived behavioral control on entrepreneurial intention will differs by nation.

In addition, entrepreneurship attitude covers three aspects such as, cognition (belief and thoughts), conation (behavior and action) and affection (emotion and feeling). The combination of these three dimensions of entrepreneurship attitude (cognition, conation and affection) persuades an individual intention to become an entrepreneur (Pihie \& Bagheri, 2011). Entrepreneurship attitude is considered to have different factors, these factors are competition (Rivalry), change, earning money (Schwarz et al, 2009), attitude towards inner control, intuition, creativity, leadership and self-efficacy (Athayde, 2009). Other researchers include inner independency (Norasmah et al, 2008) and differentiability and self-effectiveness (Florin et al, 2007) as factors of entrepreneurship attitude.

Studies have shown that there are significant relationships between societal entrepreneurship attitude and entrepreneurial intention. According to Schumpeter (1934) and Kirzner (1985), that there is a direct relationship between attitudes and entrepreneurship activities. Thus, on a societal level, there is a link between culture and entrepreneurial activity which can construct a mind set for an individual to become an entrepreneur. Sajjad, Imran, Haroon, Dad, and Munir (2010), stated that culture can influence entrepreneurial intention and have impact on it towards perceived desirability and perceived feasibility in their study titled impact of culture on entrepreneurial intention. Besides, Mariano, Gorgievski, Laguna, Stephen and Zarafshani (2011) in their study on cross-cultural approach, that there is a relationship between attitude which effect culture universal and perceived behavioral control over entrepreneurial intention. Ali, Yilmaz, and Afzal (2010) that culture vary in terms of subjective norms and attitudes, which have relationship with entrepreneurial intention. They also added that culture adversely has influence entrepreneurial intention growth. Finally, Rantanen and Toikko (2013) on entrepreneurial intention, societal entrepreneurship attitude and social values among youths in Finland which shows how how youths in Finnish state understand entrepreneurship. They saw it form a point of view as a sensible career option and it have a fairly positive that has a slight relationship with social values.

From this study, there will be a need to cover the gap found in this emigrant literature (which have been discussed above) the study, then developed a conceptual framework (figure 1) from which it proposed the following propositions: 
I. Proposition 1: There is a positive relationship between entrepreneurship education and entrepreneurial intention.

II. Proposition 2: There is a positive relationship between environmental factors and entrepreneurial intention.

III. Proposition 3: There is a positive relationship between societal entrepreneurship attitude and entrepreneurial intention.

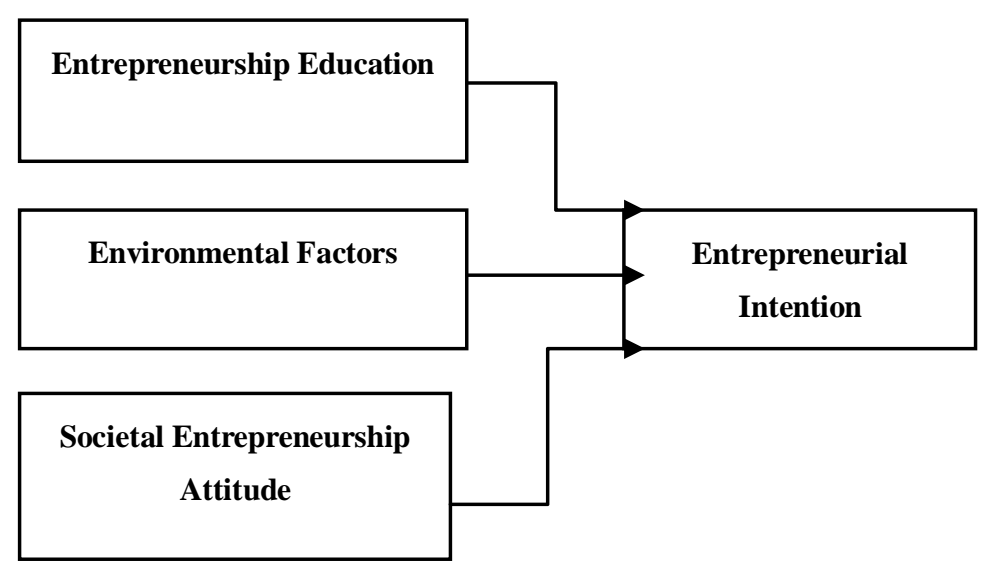

Figure 1: Conceptual Framework

\section{Conclusion and Future Research Directions}

The issue of unemployment among youth globally is becoming a serious setback faced by developing countries, which Nigeria is not left out of this issue. Teeming youth in this developing countries where now engaged in activities which can make them to be self-reliant like entrepreneurship to see whether it can solve the issue of unemployment thereby creating more opportunities for employment. In Nigeria to be more specific, government has introduce numerous policies and programs aimed towards eradicating poverty among the youth and further make them self-employed. Some of these policies and programs include introduction of entrepreneurship education as curriculum into universities and higher education institution in Nigerian.

However, after all this effort been put by government to see that youths are self-employed after graduation, still lager numbers of them remain unemployed. That means it is not just introducing policies and programs but students need to have that intention before anything can be done. Furthermore, studies have only being concentrating on developed nation but this study tries to concentrate in developing nation (Nigerian) and also from individual entrepreneurial perspective to study students' intention. In the background of this study, it was based on assessing the factors that will lead postgraduate student's entrepreneurial intention in Nigeria universities and the variables were; (entrepreneurship education, environmental factor and societal entrepreneurship attitude). The results indicated that these three variables have a positive significant impact in students' intention to become entrepreneurs. Lastly, all these findings made by this study are relevant to Nigeria government and the education Ministry to help them put in place new policies that will encourage the students' entrepreneurial intention.

\section{References}

Agbim, K. C., Oriarewo, G. O., \& Owocho, M. (2012).Factors influencing entrepreneurial intentions among graduates of Nigerian tertiary institutions. International Journal of Business and Management Invention, 2, 36-44.

Akanbi, S. T. (2013). Familial Factors, Personality Traits and Self-Efficacy as Determinants of Entrepreneurial 
Intention among Vocational Based College Of Education Students in Oyo State, Nigeria.

Alarape, A. (2009). On the road to institutionalizing entrepreneurship education in Nigerian universities. The international journal of management education, 7 (2), 81-87.

Aliman, N. K., \& Jalal, H. A. (2013).Entrepreneurial Career Intentions among Malay Ethnic University Students in Malaysia.Business \& Applied Sciences, 1, 363.

Aluwong, T., \& Bello, M. (2010). Emerging diseases and implications for Millennium Development Goals in Africa by 2015-an overview. Vet Ital, 46(2), 137-43.

Ang, S. H., \& Hong, D. (2000).Entrepreneurial spirit among East Asian Chinese. Thunderbird International Business Review, 42, 285-309.

Arogundade, B. B. (2010).Problems of Facilities in South-West Nigeria Universities and the Forward.Journal of Education Administration and Policy, 2(2), 039-043.

Awogbenle, A. C., \& Iwuamadi, K. C. (2010). Youth unemployment: Entrepreneurship development program as an intervention mechanism. African Journal of Business Management, 831-835.

Bates, D., Maechler, M., Bolker, B., \& Walker, S. (2013). lme4: Linear mixed-effects models using Eigen and S4. R package version, 1(4).

Bhandari, N. C. (2012). Relationship between students' gender, their own employment, their parents' employment, and the students' intention for entrepreneurship.Journal of Entrepreneurship Education, $15,133-144$

Bhatti, M,A \& Sundram, V,P,K;. (2015). Business Research. Malaysia: Pearson Malaysia Sdn Bhd.

Bird, B. (1988).Implementing entrepreneurial ideas: The case for intention.Academy of management review, 13, 442-453.

Blanchflower, D. G., \& Oswald, A. J. (2007). What makes a young entrepreneur? IZA Discussion Paper, 3139.

Bolton, D. L. (2012). Individual entrepreneurial orientation: further investigation of a measurement instrument. Academy of entrepreneurial journal, 18 (1), 91-97.

Brockhaus, R. H. (1987). Entrepreneurial folklore.Journal of Small Business Management, 25, 1-6.

Carvalho, M. (2013, 11th December). Focusing on entrepreneurship education, The Star. Retrieved from http://www.thestar.com.my/News/Nation/2013/12/11/Focusing-on-entrepreneurship-education/

Davidsson, P. (1995). Determinants of Entrepreneurial Intentions. Paper presented at the RENT IX Workshop, International Business School, Jonkoping, and Piacenza, Italy.

Deh, I. Y., Asuamah, S. Y., \& Agyemang, I. K. (2013). The Link between Demographics and Perceive Barriers to Entrepreneurship. Journal of Small Business and Entrepreneurship Development, 1(1), 42-50.

Diaz Garcia, M. C., \& Jiménez-Moreno, J. (2010). Entrepreneurial intention: the role of gender. International Entrepreneurship and Management Journal, 6(3), 261-283.

Dohse, D., \& Walter, S. G. (2010). The role of entrepreneurship education and regional context in forming entrepreneurial intentions: Document de treball de l'IEB.

Douglas, E. J., \& Fitzsimmons, J. R. (2013). Intrapreneurial intentions versus entrepreneurial intentions: distinct constructs with different antecedents. Small Business Economics, 41(1), 115-132.

Drnovsek, M., Wincent, J., \& Cardon, M. S. (2010). Entrepreneurial self-efficacy and business startup: Developing a multi-dimensional definition. International journal of entrepreneurial behavior \& Research, 16, 329-348.

Ekpe, I., \& Mat, N. (2012).The moderating effect of social environment on the relationship between 
entrepreneurial orientation and entrepreneurial intentions of female students at Nigerian universities. International Journal of Management Sciences and Business Research, 1, 1-16.

Ekpoh, U. I., \& Edet, A. O. (2011).Entrepreneurship education and career intentions of tertiary education students in Akwa Ibom and Cross River States, Nigeria.International Education Studies, 4(1), p172.

Esuh Ossai-Igwe, L., \& Najafi Auwalu, I. (2014).Environmental factors and entrepreneurial intention among Nigerian students in UUM.

Fatoki, O. (2014). The Entrepreneurial intention of undergraduate students in South Africa: The influences of Entrepreneurship Education and previous work experience. Mediterranean Journal of social sciences, 5,294 .

Fitzsimmons, J. R., \& Douglas, E. J. (2011).Interaction between feasibility and desirability in the formation of entrepreneurial intentions.Journal of Business Venturing, 26(4), 431-440.

Fretschner, M., \& Weber, S. (2013). Measuring and understanding the effects of entrepreneurial awareness education.Journal of Small Business Management, 51(3), 410-428.

Gana, S. (2005). Entrepreneurship Development: Jofegan Associates, Kaduna.

Gasse, Y., \& Tremblay, M. (2011). Entrepreneurial beliefs and intentions: A cross-cultural study of university students in seven countries. International Journal of Business, 16(4), 303.

Gries, T., \& Naudé, W. (2011). Entrepreneurship and human development: A capability approach. Journal of Public Economics, 95(3), 216-224.

Griffith-Jones, S., \& Ocampo, J. A. (2009).The financial crisis and its impact on developing countries (No. 53). Working Paper, International Policy Centre for Inclusive Growth.

Hair, J. F., Jr., Black, W. C., Babin, B. J., Andersen, R. E., \& Tatham, R. L. (2010).Multivariate data analysis (7th ed.). Upper Saddle River, NJ: Pearson Prentice Hall. 280.

Henderson, R., \& Robertson, M. (2000). Who wants to be an entrepreneur? Young adult attitudes to entrepreneurship as a career.Career Development International, 5(.6) 279-287.

Ireland, R. D., Hitt, M. A., \& Sirmon, D. G. (2003). A model of strategic entrepreneurship: The construct and its dimensions. Journal of management, 29, 963-989.

Ismail, M., Khalid, S. A., Othman, M., Jusoff, H. K., Rahman, N. A., Kassim, K. M., \& Zain, R. S. (2009).Entrepreneurial intention among Malaysian undergraduates.International Journal of Business and Management, 4(10), P54.

Julie, P;. (2010). SPSS Survial Manual. Australia: (4th Ed) Allen \& Unwin.

Karali, S. (2013). The impact of entrepreneurship education programs on entrepreneurial intentions: An application of the theory of planned behavior. Master Thesis. Erasmus University of Rotterdam.

Karimi, S., Chizari, M., Biemans, H. J., \& Mulder, M. (2010). Entrepreneurship education in Iranian higher education: The current state and challenges. European Journal of Scientific Research, 48, 35-50.

Keilbach, M., Tamvada, J. P., \& Audretsch, D. B. (2008).Sustaining entrepreneurship and economic growth: lessons in policy and industry innovations from Germany and India (Vol. 19): Springer.

Krueger, N. F., Reilly, M. D., \& Carsrud, A. L. (2000).Competing models of entrepreneurial intentions.Journal of Business Venturing, 15 (5/6), 411-432.

Liñán, F., Rodríguez-Cohard, J. C., \& Rueda-Cantuche, J. M. (2011). Factors affecting entrepreneurial intention levels: a role for education. International Entrepreneurship and Management Journal, 7(2), 195-218.

Liñán, F., Urbano, D., \& Guerrero, M. (2011).Regional variations in entrepreneurial cognitions: Start-up 
intentions of university students in Spain. Entrepreneurship and Regional Development, 23, 187-215.

Lucky, I., \& Minai, M. S. (2011). „The Entrepreneurial Mind of the Female Graduate-to-be in Northern Malaysia"e. Paper presented at the The Proceeding at the World Business, Economics and Finance Conference.

Luthje, C., \& Franke, N. (2003). The 'making' of an entrepreneur: testing a model of entrepreneurial intent among engineering students at MIT. R\&D Management, 33, 135-147.

Maina, S. (2014).The role of entrepreneurship education on job creation among youths in Nigeria.International Letters of Social and Humanistic Sciences, (04), 87-96.

Malebana, J. (2014). Entrepreneurial intentions of South African rural university students: A test of the theory of planned behaviour. Journal of Economics and Behavioral Studies, 6(2), 130-143.

McGee, J.E., Peterson, M., Mueller, S.L., \& Sequeira, J.M. (2009). Entrepreneurial self-efficacy: Refining the measure. Entrepreneurship theory and practice, 4, 965-988.

Minniti, M., \& Lévesque, M. (2008).Recent developments in the economics of entrepreneurship.Journal of Business Venturing, 23 ed.: 603-612.

Muofhe, N. J., \& Du Toit, W. F. (2011). Entrepreneurial education's and entrepreneurial role models' influence on career choice: original research. SA Journal of Human Resource Management, 9(1), 1-15.

National Bureau of Statistics (2014) www.nast.got.ng

Ogundipe, S. E., Kosile, B. A., \& Ogundipe, L. O. (2012).Entrepreneurial intention among business and counseling students in Lagos State University sandwich programmer.Journal of Education and Practice, 3(14), 64-72.

Olakitan, O.O (2014) The Influence of Some Personality Factors on Entrepreneurial Intentions. International Journal of Business and Social Science, 5, 278-284.

Ooi, Y.K, Christopher J, Denny M. (2011). Inclination towards entrepreneurship among university student: An empirical study of Malaysian university students. International Journal of business and social science, 2 (4), 204-220.

Oosterbeek, H., van Praag, M., \& Ijssel stein, A. (2010). The impact of entrepreneurship education on entrepreneurship skills and motivation.European economic review, 54, 442-454.

Othman, N.H. and Ishak, S. 2009. Attitude towards choosing a career in entrepreneurship amongst graduates.European Journal of Social Sciences, 10, 3, 419-434.

Owoseni, O. O. (2014). The Influence of Some Personality Factors on Entrepreneurial Intentions.International Journal of Business and Social Science, 5(1), 278-284.

Pihie, Z. L., \& Bagheri, A. (2011). Malay Secondary School Students' Entrepreneurial Attitude Orientation and Entrepreneurial Self efficacy: A Descriptive Study. Journal of Applied Sciences, 11(2), 316-322.

Poplawski, B. (2009). The history of Education in Nigeria Entrepreneurship.Hemisphere 24,105-131.

Rodrigues, R. G., Dinis, A., do Paço, A., Ferreira, J., \& Raposo, M. (2012). The effect of an entrepreneurial training programme on entrepreneurial traits and intention of secondary students.Entrepreneurship-Born, made and educated, 77-92.

Samuel, Y. A., Ernest, K., \& Awuah, J. B. (2013).An Assessment of Entrepreneurship Intention among Sunyani Polytechnic Marketing Students.International Review of Management and Marketing, 3, 37-49.

Sánchez, J. C. (2011). University training for entrepreneurial competencies: Its impact on intention of venture creation. International Entrepreneurship and Management Journal, 7, 239-254. 
Sekaran, U. \& Bougie, R. (2010).Research methods for business. A sill building approaches (5th Ed.) John Willey: UK.

Shapero, A., \& Sokol, L. (1982).The social dimension of entrepreneurship. In: Kent, C.A., Sexton, D.L., \& Vesper, K.H. (eds.) the Encyclopedia of Entrepreneurship. Englewood Cliffs, NJ: Prentice-Hall.

Singh Sandhu, M., Fahmi Sidique, S., \& Riaz, S. (2011). Entrepreneurship barriers and entrepreneurial inclination among Malaysian postgraduate students.International Journal of Entrepreneurial Behavior \& Research, 17(4), 428-449.

Solesvik, M. Z. (2013). Entrepreneurial motivations and intentions: investigating the role of education major. Education+ Training, 55, 253-271.

Temtime, Z. T., Chinyoka, S. V., \& Shunda, J. P. W. (2004).A decision tree approach for integrating small business assistance schemes.Journal of Management Development, 23(6), 563-578.

Turker, D., \& Sonmez Selçuk, S. (2009). Which factors affect the entrepreneurial intention of university students? Journal of European Industrial Training, 33 (2), 142-159.

Vecchio, R.P. 2003. Entrepreneurship and Leadership: Common Trends and Common Threads.Human Resource Management Review, 13:303-327.

Vidic, F. (2013). Entrepreneurial orientation (EO) and Knowledge creation (KC). International journal of economic sciences and applied research, 6 (2), 103-124.

Von Graevenitz, G., Harhoff, D., \& Weber, R. (2010).The effects of entrepreneurship education.Journal of Economic Behavior \& Organization, 76(1): 90-112.

Wang, W., Lu, W., \& Millington, J. K. (2011).Determinants of entrepreneurial intention among college students in China and USA.Journal of Global Entrepreneurship Research, 1, 35-44.

White, R. E., Thornhill, S., \& Hampson, E. (2007). A biosocial model of entrepreneurship: the combined effects of nurture and nature. Journal of Organizational Behavior, 28, 451-466.

Wu, W. W. (2009). A competency-based model for the success of an entrepreneurial start-up. WSEAS Transactions on Business and Economics, 6, 279-291.

Yordanova, D. I., \& Alexandrova-Boshnakova, M. I. (2011). Gender effects on risk-taking of entrepreneurs: evidence from Bulgaria. International Journal of Entrepreneurial Behavior \& Research, 17, 272-295.

Zain, Z. M., Akram, A. M., \& Ghani, E. K. (2010).Entrepreneurship intention among Malaysian business students.Canadian Social Science, 6, 34-44.

Zhao, H., Seibert, S. E., \& Lumpkin, G. T. (2010). The relationship of personality to entrepreneurial intentions and performance: A meta-analytic review. Journal of Management, 36, 381-404.

\section{Copyrights}

Copyright for this article is retained by the author(s), with first publication rights granted to the journal. 